\title{
合同シンポジウム -2
}

\section{HPV 特異的粘膜型 $\mathrm{T}$ 細胞を利用した子宮頸癌の免疫療法と 再生医療（T-iPS）の導入に向けて}

\author{
東京大学医学部 産科婦人科 \\ 川名敬
}

子宮頸癌は 30 歳代に罹患ピークがあり, 年間約 7000 人が発症し, 約 3000 人が死亡する癌である. ヒトパ ピローマウイルス (HPV) が原因であることは周知であり, HPV を標的とした癌免疫療法が期待されてきた. 20 年以上の開発の歴史の中で製剤化されたものはない，我々は，粘膜免疫を誘導する免疫療法を開発し，子 宮頸癌前癌病変（CIN3）を対象とした臨床試験を実施した。HPV 癌蛋白質 E7 を表出した乳酸菌を CIN3 患者 に経口投与し, HPV 特異的細胞性免疫を腸管粘膜に誘導し，腸管粘膜由来の integrin beta7 陽性リンパ球を子 宮頸部病変に見出した。そのうち, HPVE7 特異的 IFNgamma 産生リンパ球の子宮頸部粘膜の集積と臨床的病 変退縮は相関した。この臨床試験のデータをもとに, E7 表出乳酸菌を改良し, 現在第二世代乳酸菌ワクチン を製剤化している。一方, integrin beta7 陽性リンパ球が子宮頸部粘膜上皮にホーミングし，かつ集積すること がCIN3 病変を排除することに寄与することを見出したので, 細胞療法として，これらの細胞に山中因子を導 入する T-iPS 技術を応用することをめざしている，本講演では，これまでの粘膜免疫を介した新しい免疫療法 の臨床成果と今後の新技術（特に再生医療）との複合について紹介したい. 